OPEN ACCESS

Edited by:

Alok Srivastava

Christian Medical College and

Hospital, India

Reviewed by:

Katrina Gee,

Queen's University, Canada

Evren Alici,

Karolinska Institute (KI), Sweden

*Correspondence: Xue-Zhong Yu yux@musc.edu

Specialty section: This article was submitted to Alloimmunity and Transplantation, a section of the journal

Frontiers in Immunology

Received: 09 January 2019 Accepted: 16 April 2019 Published: 08 May 2019

Citation:

Bastian D, Wu Y, Betts BC and Yu X-Z (2019) The IL-12 Cytokine and Receptor Family in Graft-vs.-Host Disease. Front. Immunol. 10:988. doi: 10.3389/fimmu.2019.00988

\section{The IL-12 Cytokine and Receptor Family in Graft-vs.-Host Disease}

\author{
David Bastian ${ }^{1}$, Yongxia Wu ${ }^{1}$, Brian C. Betts ${ }^{2}$ and Xue-Zhong Yu ${ }^{1,3 *}$ \\ ${ }^{1}$ Department of Microbiology and Immunology, Medical University of South Carolina, Charleston, SC, United States, \\ ${ }^{2}$ Department of Medicine, University of Minnesota, Minneapolis, MN, United States, ${ }^{3}$ Department of Medicine, Medical \\ University of South Carolina, Charleston, SC, United States
}

Allogeneic hematopoietic cell transplantation (allo-HCT) is performed with curative intent for high- risk blood cancers and bone marrow failure syndromes; yet the development of acute and chronic graft-vs.-host disease (GVHD) remain preeminent causes of death and morbidity. The IL-12 family of cytokines is comprised of IL-12, IL-23, IL-27, IL-35, and IL-39. This family of cytokines is biologically distinct in that they are composed of functional heterodimers, which bind to cognate heterodimeric receptor chains expressed on T cells. Of these, IL-12 and IL-23 share a common $\beta$ cytokine subunit, $p 40$, as well as a receptor chain: IL-12R $\beta 1$. IL-12 and IL-23 have been documented as proinflammatory mediators of GVHD, responsible for T helper 1 (Th1) differentiation and Thelper 17 (Th17) stabilization, respectively. The role of IL-27 is less defined, seemingly immune suppressive via IL-10 secretion by Type 1 regulatory ( $\mathrm{Tr} 1$ ) cells yet promoting inflammation through impairing $\mathrm{CD}^{+}{ }^{+} \mathrm{T}$ regulatory (Treg) development and/or enhancing Th1 differentiation. More recently, IL-35 was described as a potent anti-inflammatory agent produced by regulatory $B$ and $T$ cells. The role of the newest member, IL-39, has been implicated in proinflammatory $\mathrm{B}$ cell responses but has not been explored in the context of allo-HCT. This review is directed at discussing the current literature relevant to each IL-12-family cytokine and cognate receptor engagement, as well as the consequential downstream signaling implications, during GVHD pathogenesis. Additionally, we will provide an overview of translational strategies targeting the IL-12 family cytokines, their receptors, and subsequent signal transduction to control GVHD.

Keywords: GVHD, signal transduction, GVT, cytokine receptor, cytokine, IL-12 cytokines, IL-12 family cytokine receptors, HCT

\section{ALLOGENEIC HEMATOPOIETIC STEM CELL TRANSPLANTATION}

Allogeneic hematopoietic cell transplantation (allo-HCT) is performed with curative intent for high-risk blood cancers and bone marrow failure syndromes. The efficacy of allo-HCT lies in the ability of donor $\mathrm{T}$ cells to mediate a potent anti-tumor response in transplant recipients, known as the graft-vs.-tumor (GVT) effect, coupled with the benefit derived from pre-transplant conditioning $(1,2)$. The success of allo-HCT is compromised by the development of graft-vs.-host-disease (GVHD), a complication mediated by mature donor $\mathrm{T}$ cells present in the graft against normal host tissue. The incidence of acute GVHD (aGVHD), a significant cause of mortality after allo-HCT, has been significantly reduced over the past decade. Transplant-related mortality has declined 
with the implementation of reduced intensity conditioning (RIC) regimens, new GVHD prophylaxis strategies, and the development of molecular methods aiding in early detection of viral and fungal infections in concert with modern anti-infectious agents (3-5). However, aGVHD still affects 20 to $70 \%$ of alloHCT patients (6). Current clinical regimens for GVHD patients are primarily based on non-specific immunosuppressants for prophylaxis and treatment, such as calcineurin inhibitors or glucocorticosteroids, respectively (7). These broadly-acting agents fail to induce immune tolerance, increase susceptibility to opportunistic infections, and compromise GVT activity (8). Research in the field is focused on reducing GVHD without compromising the GVT effect. The current consensus on the initiation of GVHD pathophysiology can be divided into three primary phases:

1) Host tissue injury caused by conditioning regimens leads to the release of proinflammatory cytokines. Tissue damage from pre- transplant conditioning regimens results in a prolonged (up to 12 weeks post allo-HCT) increase of various cytokines; these include interleukin $1 \beta$ (IL-1 $\beta$ ), interleukin 6 (IL-6), interleukin 8 (IL-8), interleukin 10 (IL-10), interleukin 12 (IL-12), interleukin 21 (IL-21), interleukin 23 (IL-23), transforming growth factor $\beta$ (TGF $\beta$ ), and tumor necrosis factor $\alpha(\mathrm{TNF} \alpha)(9-11)$. These cytokines are primarily produced by activated dendritic cells (DCs) in response to tissue damage and microbe exposure, in concert with release of damage associated molecular patterns (DAMPs), including high mobility group protein B1 (HMGB-1) and adenosine triphosphate (ATP), as well as pathogen associated molecular patterns (PAMPs), which include lipopolysaccharide (LPS) and peptidoglycan. Both DAMPs and PAMPs can activate APCs, such as DCs and macrophages.

2) Donor $T$ cell activation by activated APCs leads to differentiation into effector $\mathrm{T}$ cells, such as $\mathrm{T}$ helper type 1 (Th1) and $\mathrm{T}$ helper type 17 (Th17), both of which are pathogenic and associated with GVHD severity and mortality (12).

3) Effector T cell migration and target tissue destruction by activated donor $\mathrm{T}$ cells results in the initiation of GVHD $(12,13)$.

A myriad of cytokines, chemokines, receptors, and transcription factors are associated with $\mathrm{T}$ cell activation and associated inflammation, hence playing a central role in the development of GVHD. Classically, Th1 cells are believed to play a critical role in the induction of GVHD; although our group and others have demonstrated that Th17 cells also contribute (15). By targeting Th1 and Th17 specific transcription factors, T-box transcription factor TBX21 (T-bet) and Retinoic acid- related orphan receptor gamma (ROR $\gamma \mathrm{t})$, respectively, it was observed that both Th1 and Th17 subsets contribute to GVHD development; yet either lineage alone is sufficient to induce GVHD $(14,15)$. Thus, both lineages must to be blocked in order to control GVHD. Efficacy of targeting these $\mathrm{T}$ cell differentiation pathways at the cytokine level are under investigation in clinical trials. Strategies for protecting/promoting prompt repair of target tissues may also reduce GVHD severity.

\section{PATHOGENESIS OF ACUTE AND CHRONIC GVHD}

Acute GVHD (aGVHD) is manifested by a strong inflammatory component resulting from robust donor $\mathrm{T}$ cell activation and expansion. Prior to transplant, conditioning regimens involving chemotherapy and/or irradiation cause damage to host epithelial tissues, and subsequent release of danger signals such as chemokines and cytokines. The inflammatory milieu is then amplified by an activated innate immune response, consisting of APCs, natural killer cells (NK cells), neutrophils, and macrophages (13). Donor CD4 and CD8 T cell recognition of major or minor histocompatibility antigens, directly or indirectly, by host and donor APCs in conjunction with activation of the innate immune response creates a "cytokine storm" consisting of such components as interferon gamma (IFN $\gamma$ ), TNF $\alpha$, IL6 , IL-12, and IL-23, among others $(8,16)$. The aforementioned combination of inflammatory factors culminates in $\mathrm{T}$ cell infiltration and subsequent destruction of host tissues, namely the skin, lung, liver, and gastrointestinal tract (GI tract) (16-19).

Chronic GVHD (cGVHD) is widely systemic and can affect essentially any of the major organ systems $(8,20)$. While largely undefined, the origin of cGVHD pathogenesis has been linked to thymic damage caused by conditioning, resulting in aberrant selection and subsequent release of allo/autoreactive $\mathrm{T}$ cells (21). Older patients receiving RIC have also been observed with cGVHD, which is potentially due to reduced thymic reserve/function $(22,23)$. The activation of these $\mathrm{T}$ cells results in cytokine production and consequential activation of macrophages and fibroblasts. Chronically stimulated donor $\mathrm{T}$ cells interact with bone marrow-derived $\mathrm{B}$ cells and produce additional factors contributing to fibroblast proliferation and activation $(21,24)$. In particular, $\mathrm{T}$ follicular helper (Tfh) cells interact with B cells via CD40L-CD40 to promote B cell proliferation, differentiation, and antibody isotype switching (25). These Tfh-B cell interactions subsequently lead to germinal center formation in which antibody diversification and affinity maturation occur, ultimately leading to an adaptive immune response $(21,24,25)$. The resultant autoantibody production and tissue fibrosis lead to end organ damage (26).

\section{THE IL-12 FAMILY OF CYTOKINES AND THEIR RECEPTORS}

The IL-12 family of cytokines can direct the donor immune response to execute a range of proinflammatory and immunosuppressive functions that are relevant in GVHD (Figure 1). They are primarily secreted by cells of myeloid origin in response to inflammatory stimuli, such as microbial products or fungal infections (49). While part of the type 1 hematopoietin family of cytokines, IL-12 family members are unique in that each member is comprised of two different subunits, or heterodimers, in which either the $\alpha$ or $\beta$ subunit is shared among the others (46). The $\alpha$-subunits include p19 (IL-23/IL-39), IL-27p28 (IL-27), and p35 (IL12/IL-35). The $\beta$ - 


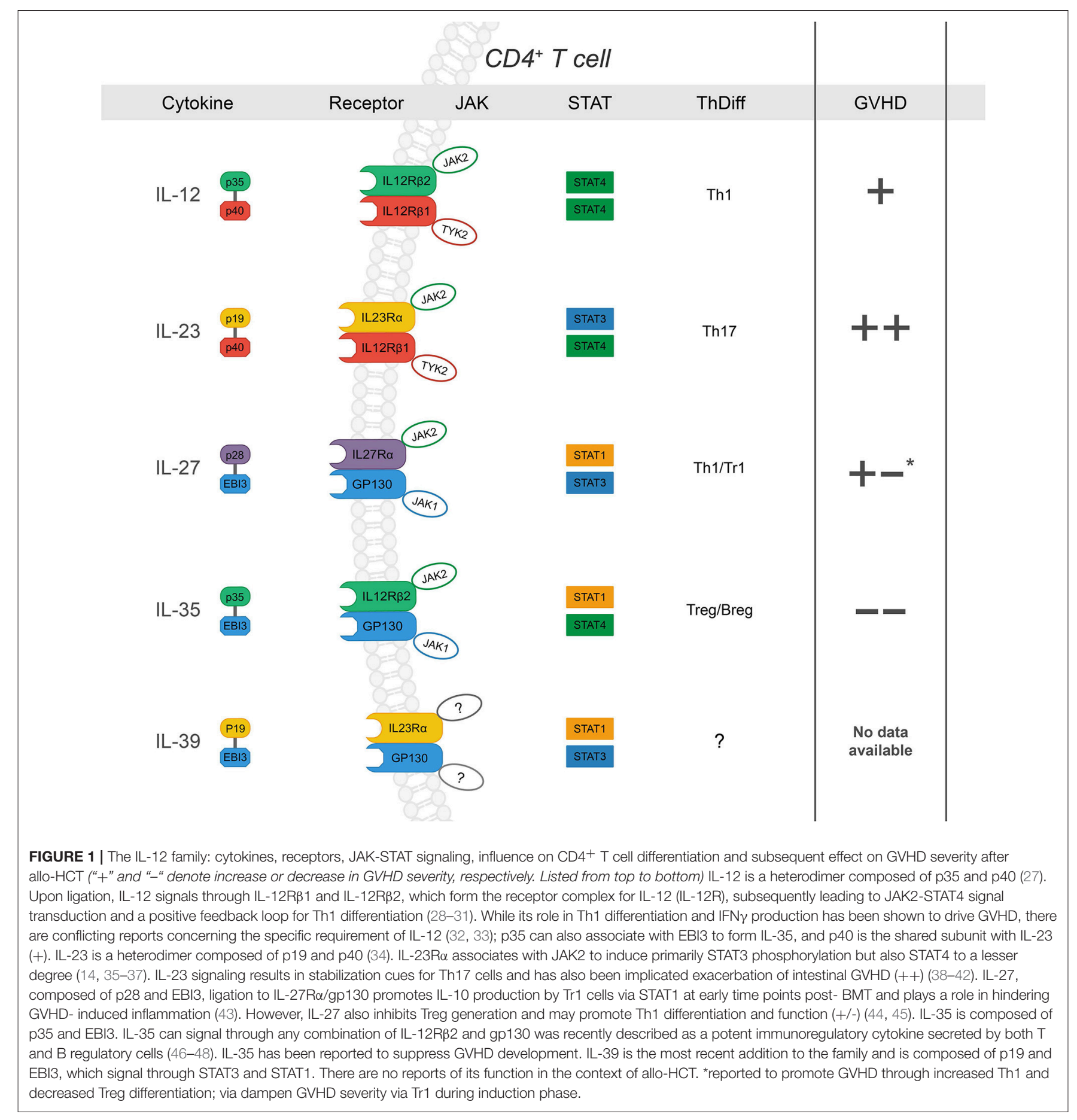

subunits include p40 (IL-12/IL-23) and Epstein-Barr virusinduced gene 3 (EBI3) (IL-27/IL-35/IL-39) (50). Further, each cytokine signals through a distinct heterodimeric receptor that is associated with its cognate subunits: IL-12R (IL-12R $\beta 2 / \mathrm{IL}-$ 12R $\beta 1$ ), IL-23R (IL-23R $\alpha /$ IL-12R $\beta 1$ ), IL-27R (IL-27R $\alpha / g p 130)$, IL-39R (IL-23R $\alpha / g p 130)$, and IL-35R (IL-12R $\beta 2 / g p 130)(46,50)$. The functionality of each respective cytokine and receptor combination ranges from proinflammatory to immune suppressive in a host of pathological and physiological conditions. Yet, similar subunits and receptors involved in proinflammatory functions can also form suppressive complexes, as in the case of IL-12R $\beta 2$, involved in IL-12 and IL-35 signaling. Therefore, deciphering the contributions of each cytokine/ receptor subunit combination is critical to understanding the immune response as a whole; the context of allo-HCT is no exception. 


\section{IL-12/IL-12R}

\section{Overview of IL-12/IL-12R Signaling}

IL- 12 consists of $\mathrm{p} 35$ and p40, and acts primarily on NK cells and T cells $(23,27)$. IL-12R $\beta 1$ binds to IL-12R $\beta 2$ to form the receptor for IL-12 (IL-12R) (27, 51). Upon ligation, IL-12R $\beta 1$ binds to Tyrosine kinase 2 (Tyk2) while IL-12R 32 binds to Janus Kinase 2 (JAK2). Tyk2 and JAK2 then phosphorylate tyrosine residues primarily on signal transducer and activator of transcription 4 (STAT4). Ultimately, the STAT4 complex trans locates to the nucleus and binds to the IFN $\gamma$ promoter; Jun oncogene (c-Jun) is also recruited to the IFN $\gamma$ promoter via STAT4 $(28,29,52)$, potentiating IFN $\gamma$ transcription, and Th1 differentiation. In a STAT4 -dependent manner, IL-12 also promotes expression of Interferon regulatory factor 1 (IRF1) and 4 (IRF4), transcription factors required for Th1 differentiation $(53,54)$. Notwithstanding the contribution of IL-12 to Th1 differentiation, IL-12/IL$12 \mathrm{R}$ also promotes $\mathrm{T}$-cell proliferation and adhesion during activation. It has been reported that IL-12 contributes to expression of Interleukin 2 receptor $\alpha(\mathrm{IL}-2 \mathrm{R} \alpha)$ by recruiting STAT4 and c-Jun to the promoter of IL-2R, thereby enhancing T cell proliferation $(55,56)$. IL-12 -induced STAT4 activation also culminates in P-selectin ligand formation, which augments $\mathrm{T}$ cell adhesion during differentiation (57-60). Furthermore, activation of IL-12/IL-12R signaling induces both positive and negative feedback queues which can either strengthen or reduce IL-12 signaling, respectively. For instance, STAT4 activation fosters transcription of IL-12R $\beta 2$ and Interleukin 18 receptor 1 (IL18R1), which cooperate to amplify IL-12 signaling and Th1 cell differentiation. While IL-12R signaling can promote proliferation via STAT5-JAK2 interactions, evidence exists that STAT5A can suppress IL-12 -induced Th1 cell differentiation through the induction of Suppressor of cytokine signaling 3 (SOCS3) (35). However, this report demonstrated that SOCS3 activity inhibits IL-12 signaling by binding to the STAT4 docking site of the IL$12 \mathrm{R} \beta 2$ subunit $(61,62)$. Hence, IL- 12 is predominately associated with Th1 differentiation, yet may simultaneously hinder this effect through mobilization of STAT5A depending on the context of disease or environment.

\section{IL-12 in T Cell Responses and GVHD}

IL-12 promotes the differentiation of primed $\mathrm{CD}^{+} \mathrm{T}$ cells into Th1 cells, which express Tbet, produce IFN $\gamma$, and play a critical role in driving GVHD $(15,51)$. On the other hand, IL-12 negatively regulates T helper type 2 (Th2) transcription factors and associated cytokine production (63). As such, IL$12 \mathrm{R} \beta 2$ expression is absent on Th2 cells but upregulated in Th1; an increase in Th2 differentiation is associated with reduced acute GVHD yet can exacerbate chronic GVHD $(64,65)$. In addition, CD40-CD40L interactions between T cells and APCs can fuel IL-12 production by APCs, which amplify innate immune cell responses through IFN $\gamma$ production (66). With regards to the IL-12 cytokine itself, the pool of available data is somewhat contradictory in the context of aGVHD. IL-12 has been reported to drive GVHD due to its stimulatory effect on Th1 cells $(67,68)$. IL-12 serum levels in aGVHD patients are increased compared to healthy controls, yet no correlation between higher grade GVHD (II-IV) and IL-12 has been observed (69) (Table 1). Conversely,
TABLE 1 | Expression levels of IL-12 family cytokines in aGVHD patients.

\begin{tabular}{lccc}
\hline aGVHD grade & $\mathbf{0 - 1}$ & $\mathbf{2 - 4}$ & References \\
\hline $\mathrm{IL}-12$ & $\uparrow$ & $\uparrow$ & $(69)$ \\
$\mathrm{IL}-23$ & $\uparrow$ & $\uparrow \uparrow$ & $(40)$ \\
$\mathrm{IL}-27$ & $\downarrow$ & $\downarrow$ & $(70)$ \\
$\mathrm{IL}-35$ & $\downarrow$ & $\downarrow \downarrow$ & $(71)$ \\
\hline
\end{tabular}

Representative table of $I L-12, I L-23, I L-27$, and $I L-35$ levels detected in the serum of patients with aGVHD. Upward arrows indicate increases compared to healthy donors, while downward arrows indicate decreases.

exogenous IL-12 administration was suggested to be protective in GVHD via an IFN $\gamma$-dependent mechanism (72). Previous studies observed that a single injection of IL-12 at the time of allo-HCT stifles GVHD in myeloablative-conditioned recipients (32, 33, 72). The protective or pathogenic role of IL-12 seemingly relies on the dose and timing IL-12 injection, and irradiation type for the recipient conditioning regimen in murine BMT models (73). In NK cells, IL-12 induces cytotoxic events through STAT4 and subsequent activation of the Perforin 1 (perforin) gene promoter (74). A recent report a describes IL-12/IL-18 activated donor NK cells mitigate GVHD but enhance GVT activity (75).

Apart from advocating Th1 responses, IL-12 plays a critical role in $\mathrm{T}$ follicular helper cell (Tfh) differentiation and function through STAT4 and Tbet $(76,77)$. Consistent with the crucial role of Tfh cells in cGVHD pathogenesis, administration of anti-p40 $\mathrm{mAb}$ in recipient mice significantly reduced $\mathrm{Tfh}$ generation and scleroderma manifestations of cGVHD after allo-HCT ${ }^{57}$. Thus, targeting one or more of the IL-12 cytokine/receptor subunits represents a promising therapeutic strategy to reduce cGVHD.

\section{IL-23/IL-23R}

\section{Overview of IL-23/IL-23R Signaling}

IL-23 consists of p19 and p40. The IL-23R is a heterodimer comprised of IL-12R $\beta 1$ and IL-23R $\alpha$. IL-23R associates with JAK2 and, in a ligand-dependent manner, with STAT3. IL23- induced activation of STAT3 leads to direct binding of phosphorylated STAT3 to IL-17A and IL-17F promoters. STAT3 up-regulates the expression of ROR $\gamma \mathrm{t}$, the master transcription factor of Th17, which is critical for the expression of two members of the Interleukin-17 family, IL-17A and IL-17F (7880). SOCS3 inhibits JAK2 activity, hence decreasing IL-17A and IL-17F expression (78).

IL-23 signaling regulates Th17 cells. IL-23 plays an important role in expanding and maintaining the Th17 cell population, a $\mathrm{T}$ cell subset involved in homeostatic antimicrobial immune responses as well as in the propagation of many autoimmune diseases (81). IL-23 is an indispensable factor for promoting pathogenicity of Th17 cells, yet is not required for initial differentiation (82-85). IL-23 has been shown to control Th17 responses through regulating $\mathrm{T}$ cell metabolism. TCR stimulation induces GLUT-1 surface expression and subsequent lactate production, promoting glucose uptake $(86,87)$. T cells under Th17 polarizing conditions undergo a HIF1- $\alpha$ - dependent metabolic switch to glycolysis, and data indicates that IL-23 might contribute to this effect via PKM2 and HIF1- $\alpha$ (88). Notably, 
allogeneic T cells were shown to depend on glycolysis for effector function during GVHD development, yet a connection to IL-23 and glycolysis has not been demonstrated. HIF1- $\alpha$ induction has also been associated with IL-23 production in dendritic cells; this link between HIF1- $\alpha$ and PKM2 has been previously established in cancer cells (89-91). Therefore, PKM2 may possess more than one function in addition to its role in glycolysis manifested by transcriptional activation as a protein kinase (92). Taken together, IL-23 signaling through PKM2/STAT3 may directly contribute to the metabolism of Th17 cells and, in concert with IL-6, could represent an essential factor for lineage commitment (93). Glucocorticoid-induced protein kinase 1 (SGK1) is critical for IL-23R expression through deactivating murine Foxo1, which directly represses IL-23R expression (94). SGK1 is essential for the induction of pathogenic Th17 cells and implicates environmental factors, such as a high-salt diet, as triggers to Th17 development and subsequent tissue inflammation (95). Lastly, while Blimp-1 IL-23-dependent Blimp-1 enhances Th17 pathogenic factors such as GM-CSF and IFN $\gamma$, and co-localizes with ROR $\gamma$ t and STAT-3 at Il23r, Ill7a, and Csf2 enhancer sites (96).

\section{IL-23 Signaling in Autoimmune Diseases}

Studies show IL-23 signaling contributes to the pathogenesis of various autoimmune diseases. In mice, it was demonstrated that bacteria-driven innate colitis is associated with an increased production of IL-17A and IFN $\gamma$ in the colon. Stimulation of intestinal leukocytes with IL-23 induced the production of IL-17 and IFN $\gamma$ exclusively by innate lymphoid cells expressing IL$23 \mathrm{R}$, which were demonstrated to accumulate in the inflamed colon. These results identified a previously unrecognized IL-23responsive innate lymphoid population that mediates intestinal immune pathology and may therefore represent a target in inflammatory bowel disease (97-99). Intestinal IL-23-responsive innate cells are also a feature of T cell-dependent models of colitis, which resembles many of the features seen in intestinal GVHD with respect to $\mathrm{T}$ cell infiltration resulting in inflammation and gut injury. The transcription factor ROR $\gamma \mathrm{t}$ controls IL23R expression, as it was shown that Rag/Rorc-null mice failed to develop innate colitis which is dependent on IL-23 (98). In addition, expression of IL-23 and IL-23R was increased in the tissues of patients with psoriasis (100). Injection of a neutralizing monoclonal antibody to IL-23p19 in a xenotransplant mouse model showed IL-23-dependent inhibition of psoriasis (100).

\section{IL-23 Signaling in GVHD}

Our group has demonstrated both Th1 and Th17 subsets are required to induce GVHD (15). Pharmacological inhibition of IL-23p19 results in reduced GVHD, and recent evidence suggests that IL-23R drives GVHD pathogenesis (38-41). These studies show that a $\mathrm{CD} 4{ }^{+} \mathrm{CD} 11 \mathrm{c}^{+} \mathrm{IL}-23 \mathrm{R}^{+} \mathrm{T}$ cell population induces colonic inflammation during GVHD, indicating a key role for IL-23R expression on donor $\mathrm{T}$ cells in mediating damage to the gut after allo-HCT. Consistently, the gene expression levels of $I L-23$ and $I L-23 R$ were upregulated in murine colons after allo-HCT (38). These studies demonstrate that the colon is specifically protected via IL-23p19 signaling blockade, and that
GVL activity is maintained. In a patient cohort, Liu et al. observed IL-23 mRNA expressions in patients with aGVHD were significantly higher than those in healthy donors, and IL23 and IL-23R expression were positively correlated with IL17 expression (101). These studies additionally showed that IL23 serum levels were elevated during the onset of aGVHD, yet decreased during disease remission (Table 1). In aGVHD, two out of three independent studies in patients found that a single nucleotide polymorphism (rs11209026) in IL-23R of donor origin reduced incidence of GVHD; the third study did not observe any effect $(19,102)$. Hence, blocking either p19 or p40 reduces aGVHD and IL-23R deficiency in donor $\mathrm{T}$ cells results in abrogated GVHD. These results indicate IL-23 also plays a key role in GVHD pathogenesis. Albeit, a recent paper demonstrated genetic inactivation of IL-23R, or the transcription factor ROR $\gamma \mathrm{t}$, within donor T cells similarly ablated Th17 cell formation in vivo but preserved the T cells' ability to induce intestinal GVHD in an indistinguishable manner compared to wild-type controls (103).

\section{Developing New Strategies to Target IL-23R}

The crystal structure of IL-23R $\alpha$ was recently reported (104). Hence, development of pharmaceutical compounds capable of specifically binding/inhibiting the IL-23R has been stagnant since its discovery in 2002. It appears that IL-23 binds IL$23 \mathrm{R}$ with an affinity of $44 \mathrm{nM}$, while binding IL-12R $\beta 1$ with an affinity of $2 \mu \mathrm{M}$; nonetheless, the affinity of the IL-23:IL-23R complex for IL-12R $\beta 1$ has been described as $25 \mathrm{nM}$, despite no apparent interaction of IL-23R with IL-12R $\beta 1$, implying that there is a cooperative effect which is likely to be due to a conformational change of IL-23 upon binding IL-23R, which is indeed observed crystallographically (104-108). In a recent publication, hydrogen-deuterium exchange mass spectrometry (HDX-MS) was used to demonstrate IL-23 binding to the $\mathrm{N}$-terminal immunoglobulin domain of IL-23R in both the solid state as well as under more physiologically relevant conditions. This data allowed specific identification of a binding epitope using a macrocyclic small molecule against IL-23R for the first time (106). However, IL-23R antagonism is not a new concept, as a peptide antagonist was shown to reduce inflammation in different models of autoimmune disease (109). The aforementioned data presents exciting new possibilities for future studies, yet efficacy of such prototype molecules requires vigorous testing in preclinical models.

\section{Interplay Between IL-12 and IL-23}

Recent findings have emphasized the need to develop therapeutics methods that enable targeting of IL-12 and IL23 signaling. Interestingly, not only do the cytokines IL-12 and IL-23 share the same cytokine subunit, p40, but also the cognate receptor, IL-12R $\beta 1$. Thus, these shared motifs provided the rationale for blocking Th1 and Th17 responses simultaneously through targeting $\mathrm{p} 40 / \mathrm{IL}-12 \mathrm{R} \beta 1$. However, p40 itself has a diverse set of functions. For example, $\mathrm{p} 40$ has a chemo attractant role for macrophages mediated by IL-12R $\beta 1$ alone, which is dependent on the intracellular domain of IL-12R $\beta 1$ to signal; these reports were published with regard to IL-12R $\beta 1$ signal transduction in response to a p40 homodimer $(110,111)$. 
With respect to alloreactive $\mathrm{T}$ cells, this $\mathrm{p} 40$ homodimer was demonstrated to have antagonistic activity for $\mathrm{CD}^{+}$IFN $\gamma$ production, yet could amplify IFN $\gamma$ production by CD ${ }^{+} \mathrm{T}$ cells (112). Hence, targeting p40 in the context of GVHD may result in enhanced Th1 responses and potentially hinder CD8 mediated GVT responses (113). IL-12R $\beta 1$ promiscuity among the IL-12 family has both assisted in the development of pharmaceuticals to target both pathways (as in the case of p40), yet also illuminated their complexity. Th1 and Th17 differentiation and stability converge at IL-12 and IL-23 signaling, respectively, as both signaling motifs share $\mathrm{p} 40$ at the cytokine level and IL-12R $\beta 1$ for downstream signal transmission. Supported by studies done in mice and men, IL-12 is documented to induce IFN $\gamma$ production by Th17 cells with respect to cytokines in the milieu, in vivo and in vitro, respectively $(114,115)$. This Th1/Th17 subset was shown in Crohns disease (114).

\section{p40 and GVHD}

Targeting p40, a shared subunit of IL-12 and IL-23 cytokines, consistently mitigates GVHD in clinical and preclinical studies. Our group and others have demonstrated that neutralization of the p40, using genetically deficient mice and pharmacological inhibition, alleviated acute and chronic GVHD in murine models through reducing Th1 and Th17 differentiation (116, 117). Recent data from Pidala et al. demonstrates in vivo IL-12/IL23p40 neutralization with ustekinumab blocks the Th1/Th17 response and improves overall survival in patients after allo-HCT (118). Notably, in other models of autoimmunity, in which Th17 is the major mediator of diseases, much of the originally allocated inflammatory actions of IL-12 have since been shown to be influenced by IL-23, as many studies prior to IL-23 identification were conducted via targeting p40 $(84,119)$. Therefore, future studies should focus on the biological differences of IL-12 and IL-23 in order to determine why IL-12 can exacerbate GVHD in some contexts yet suppress it in others, yet pharmacologically targeting p40 can be efficacious in reducing GVHD severity in experimental and clinical settings.

\section{IL-12Rß1 Deficiency in Human Diseases}

IL-12R $\beta 1$ was identified in 1994 by Chua et al. as a member of the hemopoietin receptor superfamily, an amino acid type I transmembrane protein that resembled the IL- 6 signal transducer, gp130 (120). It was not until 1996 that IL-12Rß2 was identified, which subsequently led to the identification of a high affinity IL-12 receptor complex when IL-12R $\beta 1$ and IL$12 \mathrm{R} \beta 2$ were coexpressed (27). Notably, the existing data with respect to IL-12R $\beta 1$ in murine models of GVHD is sparse, although there is an abundance regarding its role in conferring immunity to mycobacteria and other infections (121-123) in human. However, given that deficiency of IL-12R $\beta 1$ is relevant in patients, there are a plethora of case studies documenting related $\mathrm{T}$ cell responses (124). The IL12R $\beta 1$ promoter, when deficient of the -265 to -104 region, suggested the existence of an important regulatory element. Furthermore, the $-111 \mathrm{~A} / \mathrm{T}$ substitution appeared to cause decreased gene transcriptional activity, such that cells from-111A/A individuals were observed to have increased IL12R $\beta 1$ mRNA levels compared with those from $-111 \mathrm{~T}$ allele carriers. Thus, in individuals with the $-111 \mathrm{~T} / \mathrm{T}$ genotype, reduced IL12R $\beta 1$ expression may lead to augmented Th2 cytokine production in the skin, and subsequently contribute to the development of atopic dermatitis and other associated allergic diseases (125).

Of particular interest is the role of IL-12/IL-12R $\beta 1$ pathway in the induction of highly suppressive antigen-specific Th1-like Tregs from naïve Tregs (126). It was recently described that, in two patients with IL-12R $\beta 1$ deficiency, features of systemic autoimmunity, and photosensitivity were observed (127). These features are similar to transgenic mice deficient for IL-12R $\beta 2$, which develop an autoimmune syndrome consisting of anti-DNA positivity, immunocomplex glomerulonephritis, and multiorgan lymphoid infiltrates with features of vasculitis. However, IL$12 \mathrm{R} \beta 1$ deficient patients displayed substantially less circulating memory Tfh and memory B cells than healthy controls (77). In humans, TGF $\beta$ cooperates with IL-12 and IL-23 for expression of Tfh molecules: CXCR5, ICOS, IL-21, and the transcriptional regulator Bcl6 (128). Hence, data taken from studies in IL$12 \mathrm{R} \beta 1$ deficient patients suggests a regulatory role for IL-12, perhaps derived from Treg function, which may explain the contradictory results observed in murine models. Albeit, the role of IL-12 in Tfh/B cell axis seems at baseline consistent among experimental and clinical studies. While the aforementioned discrepancies are preliminary in comparison to the mass of studies documenting proinflammatory roles of IL-12, there is still much to learn in terms of IL-12 function; especially with respect to differences vs. IL-23.

\section{IL-27/IL-27R}

IL-27 is comprised of IL-27p28 and EBI3, binds to IL$27 \mathrm{R} \alpha / \mathrm{gp} 130$, and is the only member of the family that is not secreted as a functional dimer (129). In fact, IL-27p28 is also known as IL-30. As such, the biological mechanisms associated with the role of IL-27 vs. IL-30 in the immune response are ambiguous, displaying both proinflammatory and suppressive functions that seem to be dependent on the disease model. IL-30 was previously reported to antagonize IL27-mediated proinflammatory responses (130). Further, IL-30 inhibited activity by IL-6, IL-11, and IL-27 in the absence of EBI3 through gp130 binding (131). These findings support a role for IL-30 in hindering proinflammatory effects by such cytokines as IL-6. Yet, a recent report demonstrates that pharmacological blockade of IL-27p28 alleviates GVHD in mice, and resulted in augmented Treg responses (45). Consistently, our group found that IL-27R $\alpha$ expression promotes $\mathrm{T}$ cell pathogenicity during GVHD induction, and was attributable to augmented Th1 effector function (44). However, a report by Zhang et al. elegantly demonstrated the function and prevalence of Tr1 early after allo-BMT; noting a significant role in IL-10 production which could ameliorate GVHD and which was dependent on IL-27 (43). Tr1 cells differentiate in the presence of IL-27 and are the central cell type implicated in IL-27- related suppressive activity, producing IFN $\gamma$, and IL-10 simultaneously. Of note, experiments performed in the aforementioned report depleted Tregs in donor grafts before transplantation, and therefore may be the reason they saw no difference compared to similar models 
used in studies by Belle et al and those by our group. These studies can be connected in such a way that IL-27 promotes Tr1 cells early after BMT and can decrease GVHD independent of Tregs; yet in later stages IL-27 inhibits iTregs and Th2 cells and promotes Th1 differentiation; this ambiguous pattern is very similar to that seen in models of autoimmunity. Clinically, a study by Odile et al. demonstrated that membrane IL-27R $\alpha$ existed in a soluble form ( $\operatorname{sIL}-27 \mathrm{R} \alpha)$, functioning as a natural antagonist of IL-27, in healthy human serum, as well as in the serum of patients with Crohn's disease, suggesting that sIL$27 \mathrm{R} \alpha$ may play an immunoregulatory role in normal as well as pathological conditions (132). In extended studies by Liu et al. sIL-27R $\alpha$ was identified as a potential biomarker for the development of aGVHD (70). However, IL-27 levels have only been shown to positively correlate with sIL-27R, which Liu et al. suggested was protective in GVHD. Higher levels of serum sIL$27 \mathrm{R} \alpha$ correlated with lower grade aGVHD, however, did not show any correlation for the prediction of cGVHD (70). In future investigations, studies should focus on how IL-27 blockade modulates established GVHD, which is characterized by Th1mediated inflammation in the skin, gut, and liver. Additionally, it remains to be determined whether Treg cells deprived of Tbet induction by IL-27 will possess the transcriptional machinery sufficient to infiltrate into active GVHD sites. It will also be critical to determine the effects of IL-27 blockade on the GVT effect.

\section{IL-35/IL-35R}

IL-35 consists of p35 and EBI3, and functions as a regulatory cytokine released by $\mathrm{CD}^{+}{ }^{+} \mathrm{Foxp}^{+} \mathrm{T}$ regulatory cells (Tregs), as well as regulatory B cells (Bregs), to suppress inflammation, and subsequently reduce the severity of autoimmune diseases $(50,133)$. Interestingly, IL-35 signaling in Tregs was transduced via receptor combinations of IL-12R $\beta 2 / g p 130$, IL-12R $\beta 2 / \mathrm{IL}-$ $12 \mathrm{R} \beta 2$, or gp130/gp130, none of which could be clearly identified as the high affinity receptor (71). Currently, the suppressive effect of IL-35 in mouse models of aGVHD have been established by Zhang et al. (134) and Liu et al. (47). Importantly, IL-35 levels in the serum of aGVHD patients was significantly decreased in higher grade GVHD (II-IV) compared to lower grade (0-I) (47) (Table 1). Liu et al. (47) Collectively, these studies demonstrate that IL-35 is associated with higher frequencies of Tregs, reduced Th1 differentiation, reduced GVHD when combined with rapamycin, and evidence indicating maintenance of GVL activity $(47,134)$. However, IL-35 within the tumor microenvironment may oppose $\mathrm{T}$ cell responses required for GVT response by inducing effector exhaustion (135). Given the potential regulatory effects mediated by IL-35, we speculate the cytokine may be relevant in controlling cGVHD. Further, a recent publication by Yin et al. demonstrated that IL-35 administration skewed $\mathrm{T}$ cell differentiation from Th17 to Treg in islet cell transplantation models (136). IL-35 is clearly immunoregulatory and potentially useful in GVHD prevention, but a better understanding of its impact on $\mathrm{T}$ cell anti-tumor responses is needed prior to clinical translation.

\section{IL-39/IL-39R}

IL-39 has been proposed to consist of p19 and EBI3, and is the most recent addition to the family (137). Wang et al. published the first report describing the function of an additional heterodimer that involves p19 complexed with a subunit other than p40. IL-39 is secreted by activated B cells and was demonstrated to be significantly elevated in lupus models compared to other IL-12 members using MRL/lpr mice (137). The receptor for IL-39 was determined to be formed by dimerization of IL-23R and gp130 and signal through STAT1 and 3. While associated with neutrophil differentiation and expansion, the proinflammatory effects of IL-39 have yet to be fully defined. In a different report by Ramnath et al. IL-39 was shown to be secreted by keratinocytes and contribute to wound healing (138). While the function of IL-39 may be context dependent, these disparate reports indicate that IL-39 may also act on a broad range of cell types. Hence, further clarification regarding the general role of IL-39 in immunity is required in order to determine its effect in GVHD.

\section{INTERPLAY BETWEEN IL-6 AND IL-12 SUPER FAMILIES}

While promiscuity among IL-12 cytokine and/or receptor family is a common theme, the degree of association with glycoprotein 130 (gp130), better known for its role in IL-6 signaling, has become an intriguing area of research. Gp130 forms the link between "IL-6R/IL-12R" families, which collectively include Leukemia Inhibitory Factor Receptor (LIF-R), IL-12R $\beta 1$, IL12R $\beta 2$, Granulocyte Colony-Stimulating Factor Receptor (GCSF$\mathrm{R}$ ), and Oncostatin-M Receptor (OSM-R); and serves as a shared signal-transducing subunit for IL-6, IL-11, Leukemia Inhibitory Factor (LIF), Oncostatin-M (OSM), Cilliary Neurotrophic Factor (CNTF), Cardiotrophin-1 (CT-1), Cardiotrophin-like cytokine (CLC), and IL-27(139, 140). Importantly, gp130 is welldocumented for its capacity to transduce signals, especially for IL-6, a staple cytokine involved in inflammation. The complex of IL-6 and IL-6R binds to the ubiquitously expressed receptor subunit gp130, which forms a homodimer and thereby initiates intracellular signaling via the JAK/STAT and the MAPK pathways. IL-6R expressing cells can cleave the receptor protein to generate a soluble IL-6R (sIL-6R), which can still bind IL-6 and can associate with gp130 and induce signaling even on cells, which do not express IL-6R. This paradigm has been called IL-6 trans-signaling whereas signaling via the membrane bound IL-6R is referred to as classic signaling (139-141).

\section{TRANSLATIONAL POTENTIAL FOR TARGETING THE IL-12/IL-12R FAMILY}

\section{Targeting IL-12 and IL-23 Cytokines}

Regarding clinically translatable approaches targeting the IL-12 family, ustekinumab targets the p40 shared subunit between IL23 and IL-12. Ustekinumab added to tacrolimus and rapamycin was shown to be safe and effective for GVHD prophylaxis after related or unrelated allo-HCT. In a randomized, blinded, 
placebo-controlled study, ustekinumab significantly improved overall survival, and CRFS (Conditional Random Fields Score), a novel composite endpoint including moderate/severe cGVHD and relapse-free survival (118). Guselkumab and tildrakizumab, two monoclonal antibodies against p19, approved for treatment of plaque psoriasis $(142,143)$. However, these specific neutralizing antibodies against p19 have yet to be evaluated in GVHD patients. While inhibiting JAK2 signal transduction by IL-12 and IL-23 is a promising strategy, the question pertaining to how the shared or disparate receptors contribute to signal transduction and the consequential effect on $\mathrm{T}$ cell differentiation in allo-HCT remains unclear. The advancement of targeted pharmacological compounds specific for IL-12 or IL-23 signaling will be required to adequately dissect these scientific questions appropriately across species.

\section{Targeting IL-12 Family and Infection}

The use of any immunosuppressive agent carries the theoretical risk of impairing host defense responses to pathogens and/or decreased tumor surveillance. Relative risks of targeting IL12 and/or IL-23 are well-documented with respect to potential risk of infections. When challenged with Mycobacterium, Salmonella or Candida, mice lacking IL-12p35, IL-12p19, and IL-12/23p40 have phenotypes that generally mirror what has been observed in humans. As mentioned earlier, studies of IL$12 / 23$ p 40 and IL-12R $\beta 1$ deficiencies indicate that human IL-12 and IL-23 are redundant in host defense to many pathogens. Importantly, allo-HCT recipients treated with ustekinumab did not experience any increase in opportunistic infections or reactivation of CMV, EBV, or HHV6 compared to the placebo arm (118).

\section{DOWNSTREAM SIGNALING BY THE IL-12/IL-12R FAMILIES AND RELEVANT TRANSLATIONAL POTENTIAL \\ Jak2: The Center of IL-12/IL-12R Family Signaling}

Both IL-12R and IL-23R have been demonstrated to signal via JAK2; JAK2 deficient donor T cells or JAK2 inhibition with pacritinib were demonstrated to significantly alleviate GVHD in murine models via spared Treg differentiation and reductions in Th1 and Th17 differentiation in in mouse and human $\mathrm{T}$ cells (144). This is consistent with reports describing a common reliance on JAK2 by both IL-12 and IL-23. A key difference in downstream signaling is that IL-12 phosphorylates primarily STAT4, while IL-23 mainly induces STAT3 phosphorylation. Betts et al. reported that at 20 days post allo-HCT, pSTAT3 was significantly increased in $\mathrm{CD}^{+} \mathrm{T}$ cells among patients who would later develop aGVHD; a signaling pathway known to directly drive the transcription of Th17 lineage-specific genes (14).

JAK2 signal transduction is implicated in human autoimmune syndromes and GVHD. IL-6, IL-12, and IL-23 mediate inflammation and activate $\mathrm{T}$ cells via JAK2 (14, 145148). Blocking the IL-6 receptor with the monoclonal antibody tocilizumab has demonstrated efficacy in a phase II GVHD prevention trial (149). Tocilizumab, however, does not fully impair pathogenic Th1/Th17 responses (150), which may be attributed to the IL-12 and IL-23 receptor signaling-induced JAK2 activation to promote Th1 and Th17 differentiation, respectively. Neutralization of these p40 cytokines prevents GVHD in murine models, and may have activity in treating patients with steroid refractory GVHD (151).

\section{JAK2 Inhibition in GVHD}

JAK2 inhibition is an alternative approach to suppress IL6 and p40 receptor signal transduction and induce durable tolerance to alloantigens. JAK2 inhibitors are clinically efficacious in myelofibrosis, a hematological disease often driven by constitutive JAK2 activation (152). The existing evidence regarding JAK2 as a therapeutic target for acute GVHD is primarily supported by observations using ruxolitinib, an equimolar inhibitor of JAK1 and JAK2 (153-156). Ruxolitinib has been previously demonstrated as efficacious in treating steroidrefractory GVHD, and is clearly immunosuppressive. In part, JAK1 mediates the biologic effects of common gamma chain cytokines, including IL-2 and IL-15. Ruxolitinib suppresses hostreactive $\mathrm{T}$ cells in mice and humans. Although not observed in murine transplant studies, ruxolitinib treatment reduces the quantity of Tregs as well as the beneficial effects of NK cells in myelofibrosis patients (157-159). Therefore, a JAK2 inhibitor has the potential to prevent GVHD without conceding JAK1mediated functions provided by donor lymphocytes. Further research determining the differential effects of JAK1 and JAK2 is required to resolve these conundrums.

Given the recent discovery of IL-39 (p19/EBI3) and its cognate receptor (IL-23Ra/gp130), the question pertaining to the individual requirement for each particular cytokine/receptor complex becomes much more complex. IL-39R was shown to signal via STAT1/ STAT3 pathways, which overlaps with IL-27 and IL-23 signaling, respectively. The manner by which IL-39R and IL-23R on T cells may differentially or similarly impact the $\mathrm{T}$ cell response in allo-HCT requires further investigation.

\section{CONCLUSION}

The interplay between IL-6/IL-12 family members pertaining to $\mathrm{T}$ cell differentiation requires further investigation in the field of allo-HCT. Specific neutralizing antibodies against receptor subunits, such as IL-23R $\alpha$, are in development but have yet to be evaluated in preclinical models. While inhibiting JAK2 signal transduction by IL-12 and IL-23 is a promising strategy, the question pertaining to how the shared or disparate receptors contribute to signal transduction and the consequential effect on $\mathrm{T}$ cell differentiation in allo-HCT remains unclear. The advancement of targeted pharmacological compounds specific for IL-12 or IL-23 signaling will be required to adequately dissect these scientific questions appropriately across species. 


\section{AUTHOR CONTRIBUTIONS}

DB wrote the manuscript. YW, X-ZY, and BB edited and revised the manuscript.

\section{REFERENCES}

1. Kolb HJ. Graft-versus-leukemia effects of transplantation and donor lymphocytes. Blood. (2008) 112:4371-83. doi: 10.1182/blood-2008-03-077974

2. Thomas ED, Lochte HL, Lu WC, Ferrebee JW. Intravenous infusion of bone marrow in patients receiving radiation and chemotherapy. $N$ Engl J Med. (1957) 257:491-6. doi: 10.1056/NEJM195709122571102

3. Cutler C, Logan B, Nakamura R, Johnston L, Choi S, Porter D, et al. Tacrolimus/sirolimus vs tacrolimus/methotrexate as GVHD prophylaxis after matched, related donor allogeneic HCT. Blood. (2014) 257:491-6. doi: 10.1182/blood-2014-04-567164

4. Ganguly S, Ross DB, Panoskaltsis-Mortari A, Kanakry CG, Blazar BR, Levy RB, et al. Donor CD4+Foxp3+regulatory $\mathrm{T}$ cells are necessary for posttransplantation cyclophosphamide-mediated protection against GVHD in mice. Blood. (2014) 124:2131-41. doi: 10.1182/blood-2013-10-525873

5. Scott BL, Pasquini MC, Logan BR, Wu J, Devine SM, Porter DL, et al. Myeloablative versus reduced-intensity hematopoietic cell transplantation for acute myeloid leukemia and myelodysplastic syndromes. J Clin Oncol. (2017) 35:JCO.2016.70.709. doi: 10.1200/JCO.2016.70.7091

6. Pasquini, MC WZ, Pasquini M, Wang Z. Current use and outcome of hematopoietic stem cell transplantation. (2013) 23:1417-21. doi: 10.1016/j.bbmt.2017.05.035

7. Zeiser R, Nguyen VH, Beilhack A, Buess M, Schulz S, Baker J, et al. Inhibition of $\mathrm{CD} 4+\mathrm{CD} 25+$ regulatory $\mathrm{T}$-cell function by calcineurin-dependent interleukin-2 production. Blood. (2006) 108:390-9. doi: 10.1182/blood-2006-01-0329

8. McDonald-Hyman C, Turka LA, Blazar BR. Advances and challenges in immunotherapy for solid organ and hematopoietic stem cell transplantation. Sci Transl Med. (2015) 7:280rv2. doi: 10.1126/scitranslmed.aaa6853

9. Dudakov JA, Hanash AM, van den Brink MRM. (2015). Interleukin-22: Immunobiology and Pathology. Annu Rev Immunol. doi: 10.1146/annurev-immunol-032414-112123

10. McGeachy MJ, Chen Y, Tato CM, Laurence A, Joyce-Shaikh B, Blumenschein $\mathrm{WM}$, et al. The interleukin 23 receptor is essential for the terminal differentiation of interleukin 17-producing effector T helper cells in vivo. Nat Immunol. (2009) 10:314-24.doi: 10.1038/ni.1698

11. Zenewicz LA, Flavell RA. Recent advances in IL-22 biology. Int Immunol. (2011) 23:159-63. doi: 10.1093/intimm/dxr001

12. Longo DL, Zeiser R, Blazar BR. Acute graft-versus-host disease-biologic process, prevention, and therapy. $N$ Engl J Med. (2017) 377:2167-79. doi: 10.1056/NEJMra1609337

13. Toubai T, Mathewson ND, Magenau J, Reddy P. Danger signals and graftversus-host disease: current understanding and future perspectives. Front Immunol. (2016) 7:539. doi: 10.3389/fimmu.2016.00539

14. Betts BC, Sagatys EM, Veerapathran A, Lloyd MC, Beato F, Lawrence $\mathrm{HR}$, et al. CD4 $+\mathrm{T}$ cell STAT3 phosphorylation precedes acute GVHD, and subsequent Th17 tissue invasion correlates with GVHD severity and therapeutic response. J Leukoc Biol. (2015) 97:807-819. doi: 10.1189/jlb.5A1114-532RR

15. Yu Y, Wang D, Liu C, Kaosaard K, Semple K, Anasetti C, et al. Prevention of GVHD while sparing GVL effect by targeting Th1 and Th17 transcription factor T-bet and ROR $\gamma$ t in mice. Blood. (2011) 118:5011-20. doi: 10.1182/blood-2011-03-340315

16. Welniak LA, Blazar BR, Murphy WJ. Immunobiology of allogeneic hematopoietic stem cell transplantation. Annu Rev Immunol. (2007) 25:139-70. doi: 10.1146/annurev.immunol.25.022106.1 41606

17. Chen YB, McDonough S, Chen H, Kennedy J, Illiano C, Attar EC, et al. Expression of $\alpha 4 \beta 7$ integrin on memory CD $8+T$ cells at the presentation

\section{FUNDING}

All extramural sources of funding received for the research are reported.

of acute intestinal GVHD. Bone Marrow Transplant. (2013) 48:598-603. doi: 10.1038/bmt.2012.191

18. Koyama M, Cheong M, Markey KA, Gartlan KH, Kuns RD, Locke $\mathrm{KR}$, et al. Donor colonic CD103+ dendritic cells determine the severity of acute graft-versus-host disease. J Exp Med. (2015) 212:1303-21. doi: 10.1084/jem.20150329

19. Nguyen Y, Al-Lehibi A, Gorbe E, Li E, Haagenson M, Wang T, et al. Insufficient evidence for association of NOD2/CARD15 or other inflammatory bowel disease-associated markers on GVHD incidence or other adverse outcomes in T-replete, unrelated donor transplantation. Blood. (2010) 115:3625-3631. doi: 10.1182/blood-2009-09-243840

20. Lee SJ, Vogelsang G, Flowers MED. Chronic graft-versus-host disease. Biol Blood Marrow Transplant. (2003) 9:215-33. doi: 10.1053/bbmt.2003.50026

21. Wu T, Young JS, Johnston H, Ni X, Deng R, Racine J, et al. Thymic damage, impaired negative selection, and development of chronic graft-versus-host disease caused by donor CD4+ and CD8+ T cells. J Immunol. (2013b) 191:488-99. doi: 10.4049/jimmunol.1300657

22. MacDonald KPA, Betts BC, Couriel D. Reprint of: emerging therapeutics for the control of chronic graft-versus-host disease. Biol Blood Marrow Transplant. (2018) 24:S7-S14. doi: 10.1016/j.bbmt.2017.12.788

23. Murphy CA, Langrish CL, Chen Y, Blumenschein W, McClanahan T, Kastelein RA, et al. Divergent pro- and antiinflammatory roles for IL-23 and IL-12 in joint autoimmune inflammation. J Exp Med. (2003) 198:1951-7. doi: $10.1084 / \mathrm{jem} .20030896$

24. Deng R, Hurtz C, Song Q, Yue C, Xiao G, Yu H, et al. Extrafollicular $\mathrm{CD} 4+\mathrm{T}-\mathrm{B}$ interactions are sufficient for inducing autoimmunelike chronic graft-versus-host disease. Nat Commun. (2017) 8:978. doi: 10.1038/s41467-017-00880-2

25. Jin H, Ni X, Deng R, Song Q, Young J, Cassady K, et al. Antibodies from donor $\mathrm{B}$ cells perpetuate cutaneous chronic graft-versus-host disease in mice. Blood. (2016) 127:2249-60. doi: 10.1182/blood-2015-09-668145

26. Du J, Paz K, Flynn R, Vulic A, Robinson TM, Lineburg KE, et al. Pirfenidone ameliorates murine chronic GVHD through inhibition of macrophage infiltration and TGF- $\beta$ production. Blood. (2017) 129:2570-80. doi: 10.1182/blood-2017-01-758854

27. Presky DH, Yang H, Minetti LJ, Chua AO, Nabavi N, Wu CY, et al. A functional interleukin 12 receptor complex is composed of two beta-type cytokine receptor subunits. Proc Natl Acad Sci USA. (1996) 93:14002-7. doi: 10.1073/PNAS.93.24.14002

28. Jacobson NG, Szabo SJ, Weber-Nordt RM, Zhong Z, Schreiber RD, Darnell $\mathrm{JE}$, et al. Interleukin 12 signaling in T helper type 1 (Th1) cells involves tyrosine phosphorylation of signal transducer and activator of transcription (Stat)3 and Stat4. J Exp Med. (1995) 181:1755-62.

29. Kusaba H, Ghosh P, Derin R, Buchholz M, Sasaki C, Madara K, et al. Interleukin-12-induced interferon-gamma production by human peripheral blood T cells is regulated by mammalian target of rapamycin (mTOR). J Biol Chem. (2005) 280:1037-43 doi: 10.1074/jbc.M405204200

30. Bacon CM, Petricoin EF, Ortaldo JR, Rees RC, Larner AC, Johnston JA, et al. Interleukin 12 induces tyrosine phosphorylation and activation of STAT4 in human lymphocytes. Proc Natl Acad Sci USA. (1995) 92:7307-11. doi: $10.1073 /$ pnas.92.16.7307

31. Yao BB, Niu P, Surowy CS, Faltynek CR. Direct interaction of STAT4 with the IL-12 receptor. Arch Biochem Biophys. (1999) 368:147-55. doi: 10.1006/abbi.1999.1302

32. Dey BR, Yang YG, Szot GL, Pearson DA, Sykes M. Interleukin-12 inhibits graft-versus-host disease through an Fas-mediated mechanism associated with alterations in donor T-cell activation and expansion. Blood. (1998) 91:3315-22.

33. Sykes M, Szot GL, Nguyen PL, Pearson DA. Interleukin-12 inhibits murine graft-versus-host disease. Blood. (1995) 86:2429-38. 
34. Oppmann B, Lesley R, Blom B, Timans JC, Xu Y, Hunte B, et al. Novel p19 protein engages IL-12p40 to form a cytokine, IL-23, with biological activities similar as well as distinct from IL-12. Immunity. (2000) 13:715-25. doi: 10.1016/S1074-7613(00)00070-4

35. Ahn HJ, Tomura M, Yu WG, Iwasaki M, Park WR, Hamaoka T, et al. Requirement for distinct Janus kinases and STAT proteins in $\mathrm{T}$ cell proliferation versus IFN-gamma production following IL-12 stimulation. $J$ Immunol. (1998) 161:5893-900.

36. Floss DM, Klocker T, Schroder J, Lamertz L, Mrotzek S, Strobl B, et al. Defining the functional binding sites of interleukin 12 receptor 1 and interleukin 23 receptor to Janus kinases. Mol Biol Cell. (2016) 27:2301-16. doi: $10.1091 / \mathrm{mbc}$.E14-12-1645

37. Parganas E, Wang D, Stravopodis D, Topham DJ, Marine JC, Teglund S, et al. Jak2 is essential for signaling through a variety of cytokine receptors. Cell. (1998) 93:385-95. doi: 10.1016/S0092-8674(00)81167-8

38. Das R, Chen X, Komorowski R, Hessner MJ, Drobyski WR. Interleukin23 secretion by donor antigen-presenting cells is critical for organspecific pathology in graft-versus-host disease. Blood. (2009) 113:2352-62. doi: 10.1182/blood-2008-08-175448

39. Das R, Komorowski R, Hessner MJ, Subramanian H, Huettner CS, Cua D, et al. Blockade of interleukin-23 signaling results in targeted protection of the colon and allows for separation of graft-versushost and graft-versus-leukemia responses. Blood. (2010) 115:5249-58. doi: 10.1182/blood-2009-11-255422

40. Thompson JS, Chu Y, Glass JF, Brown SA. Absence of IL-23p19 in donor allogeneic cells reduces mortality from acute GVHD. Bone Marrow Transplant. (2010) 45:712-22. doi: 10.1038/bmt.2009.215

41. Zhou V, Agle K, Chen X, Beres A, Komorowski R, Belle L, et al. A colitogenic memory CD4+T cell population mediates gastrointestinal graft-versus-host disease. J Clin Invest. (2016) 126:3541-55. doi: 10.1172/JCI80874

42. Parham C, Chirica M, Timans J, Vaisberg E, Travis M, Cheung J, et al. A receptor for the heterodimeric cytokine IL-23 is composed of IL-12R 1 and a novel cytokine receptor subunit, IL-23R. J Immunol. (2002) 168:5699-708. doi: 10.4049/jimmunol.168.11.5699

43. Zhang P, Lee JS, Gartlan KH, Schuster IS, Comerford I, Varelias A, et al. Eomesodermin promotes the development of type 1 regulatory $T\left(\begin{array}{l}T \\ R\end{array}\right)$ cells. Sci Immunol. (2017) 2:eaah7152. doi: 10.1126/sciimmunol.aah7152

44. Bastian D, Liu Y, Wu Y, Schutt S, Nguyen HD, Sofi MH, et al. IL-27 Receptor signaling on T cells augments GVHD severity through enhancing Th1 responses. J Immunol Res Ther. (2018) 2:151-157.

45. Belle L, Agle K, Zhou V, Yin-Yuan C, Komorowski R, Eastwood D, et al. Blockade of interleukin-27 signaling reduces GVHD in mice by augmenting Treg reconstitution and stabilizing Foxp3 expression. Blood. (2016) 128:2068-82. doi: 10.1182/blood-2016-02-698241

46. Vignali DAA, Kuchroo VK. IL-12 family cytokines: immunological playmakers. Nat Immunol. (2012) 13:722-8. doi: 10.1038/ni.2366

47. Liu Y, Wu Y, Wang Y, Cai Y, Hu B, Bao G, et al. IL-35 mitigates murine acute graft-versus-host disease with retention of graft-versus-leukemia effects. Leukemia. (2015) 29:939-46. doi: 10.1038/leu.2014.310

48. Collison LW, Delgoffe GM, Guy CS, Vignali KM, Chaturvedi V, Fairweather $\mathrm{D}$, et al. The composition and signaling of the IL-35 receptor are unconventional. Nat Immunol. (2012) 13:290-9. doi: 10.1038/ni.2227

49. Thompson A, Orr SJ. Emerging IL-12 family cytokines in the fight against fungal infections. Cytokine. (2018) 111:398-407. doi: 10.1016/j.cyto.2018.05.019

50. Garbers C, Hermanns HM, Schaper F, Müller-Newen G, Grötzinger J, Rose-John S, et al. Plasticity and cross-talk of Interleukin 6type cytokines. Cytokine Growth Factor Rev. (2012) 23:85-97. doi: 10.1016/j.cytogfr.2012.04.001

51. Wu C-Y, Wang X, Gadina M, O’Shea JJ, Presky DH, Magram J. IL-12 Receptor 2 (IL-12R 2)-Deficient Mice Are Defective in IL-12-Mediated Signaling Despite the Presence of High Affinity IL-12 Binding Sites. J Immunol. (2000) 165:6221-8. doi: 10.4049/jimmunol.165.11.6221

52. Thierfelder WE, Van Deursen JM, Yamamoto K, Tripp RA, Sarawar SR, Carson RT, et al. Requirement for Stat4 in interleukin-12-mediated responses of natural killer and T cells. Nature. (1996) 382:171-4. doi: 10.1038/38 $2171 \mathrm{a} 0$
53. Galon J, Sudarshan C, Ito S, Finbloom D, O'Shea JJ. IL-12 induces IFN regulating factor-1 (IRF-1) gene expression in human NK and T cells. $J$ Immunol. (1999) 162:7256-62.

54. Lehtonen A, Lund R, Lahesmaa R, Julkunen I, Sareneva T, Matikainen S. IFN- $\alpha$ and IL-12 activate IFN regulatory factor 1 (IRF-1), IRF-4, and IRF8 gene expression in human NK and T cells. Cytokine. (2003) 24:81-90. doi: 10.1016/j.cyto.2003.07.001

55. Foukas LC, Panayotou G, Shepherd PR. Direct interaction of major histocompatibility complex class II-derived peptides with class Ia phosphoinositide 3-kinase results in dose-dependent stimulatory effects. $J$ Biol Chem. (2004) 279:7505-11. doi: 10.1074/jbc.M303999200

56. Yanagida T, Kato T, Igarashi O, Inoue T, Nariuchi H. Second signal activity of IL-12 on the proliferation and IL-2R expression of T helper cell-1 clone. J Immunol. (1994) 152:4919-28. doi: 10.4049/jimmunol.168.12.6506

57. Lim YC, Henault L, Wagers AJ, Kansas GS, Luscinskas FW, Lichtman AH. Expression of functional selectin ligands on Th cells is differentially regulated by IL-12 and IL-4. J Immunol. (1999) 162:3193-201.

58. Lim Y-C, Xie H, Come CE, Alexander SI, Grusby MJ, Lichtman $\mathrm{AH}$, et al. IL-12, STAT4-dependent up-regulation of CD4+ $\mathrm{T}$ cell core 2-1,6-n-acetylglucosaminyltransferase, an enzyme essential for biosynthesis of P-selectin ligands. J Immunol. (2001) 167:4476-84. doi: 10.4049/jimmunol.167.8.4476

59. Underhill GH, Zisoulis DG, Kolli KP, Ellies LG, Marth JD, Kansas GS. A crucial role for T-bet in selectin ligand expression in T helper 1 (Th1) cells. Blood. (2005) 106:3867-73. doi: 10.1182/blood-2005-03-0984

60. White SJ, Underhill GH, Kaplan MH, Kansas GS. Cutting edge: differential requirements for Stat 4 in expression of glycosyltransferases responsible for selectin ligand formation in Th1 cells. J Immunol. (2001) 167:628-31. doi: 10.4049/jimmunol.167.2.628

61. Takatori H, Nakajima H, Kagami S, Hirose K, Suto A, Suzuki K, et al. Stat5a inhibits IL-12-induced Th1 cell differentiation through the induction of suppressor of cytokine signaling 3 expression. J Immunol. (2005) 174:410512. doi: 10.4049/jimmunol.174.7.4105

62. Yamamoto K, Yamaguchi M, Miyasaka N, Miura O. SOCS-3 inhibits IL-12induced STAT4 activation by binding through its SH2 domain to the STAT4 docking site in the IL-12 receptor $\beta 2$ subunit. Biochem Biophys Res Commun. (2003) 310:1188-93. doi: 10.1016/j.bbrc.2003.09.140

63. Yi T, Chen Y, Wang L, Du G, Huang D, Zhao D, et al. Reciprocal differentiation and tissue-specific pathogenesis of Th1, Th2, and Th17 cells in graft-versus-host disease. Blood. (2009) 114:3101-12. doi: 10.1182/blood-2009-05-219402

64. Imanguli MM, Swaim WD, League SC, Gress RE, Pavletic SZ, Hakim FT. Increased T-bet + cytotoxic effectors and type $\mathrm{i}$ interferonmediated processes in chronic graft-versus-host disease of the oral mucosa. Blood. (2009) 113:3620-30. doi: 10.1182/blood-2008-07-1 68351

65. Korholz D, Kunst D, Hempel L, Sohngen D, Heyll A, Bonig H, et al. Decreased interleukin 10 and increased interferon-gamma production in patients with chronic graft-versus-host disease after allogeneic bone marrow transplantation. Bone Marrow Transpl. (1997) 19:691-5. doi: 10.1038/sj.bmt.1700718

66. Rose-John S, Scheller J, Schaper F. "Family reunion" - A structured view on the composition of the receptor complexes of interleukin-6-type and interleukin-12-type cytokines. Cytokine Growth Factor Rev. (2015) 26:471-4. doi: 10.1016/j.cytogfr.2015.07.011

67. Williamson E, Garside P, Bradley J, a, Mowat, a M. IL-12 is a central mediator of acute graft-versus-host disease in mice. J Immunol. (1996) 157:689-99. doi: 10.4049/jimmunol.169.3.1535

68. Williamson E, Garside P, Bradley JA, More IA, Mowat AM. Neutralizing IL12 during induction of murine acute graft-versus-host disease polarizes the cytokine profile toward a Th2-type alloimmune response and confers long term protection from disease. J Immunol. (1997) 159:1208-15.

69. Reddy V, Winer AG, Eksioglu E, Meier-Kriesche HU, Schold JD, Wingard JR. Interleukin 12 is associated with reduced relapse without increased incidence of graft-versus-host disease after allogeneic hematopoietic stem cell transplantation. Biol Blood Marrow Transplant. (2005) 11:1014-21. doi: 10.1016/j.bbmt.2005.08.032 
70. Liu S, Han J, Gong H, Li Y, Bao X, Qi J, et al. Soluble interleukin-27 receptor alpha is a valuable prognostic biomarker for acute graft-versus-host disease after allogeneic haematopoietic stem cell transplantation. Sci Rep. (2018) 8:10328. doi: 10.1038/s41598-018-28614-4

71. Wang R.-X, Yu C.-R, Dambuza IM, Mahdi RM, Dolinska MB, Sergeev, Y. $\mathrm{V}$, et al. Interleukin-35 induces regulatory B cells that suppress autoimmune disease. Nat Med. (2014) 20:633-41. doi: 10.1038/nm.3554

72. Yang YG, Dey B, Sergio JJ, Sykes M. Interleukin-12 prevents severe acute graft-versus-host disease (GVHD) and GVHD-associated immune dysfunction in a fully major histocompatibility complex haplotypemismatched murine bone marrow transplantation model. Transplantation. (1997) 64:1343-52. doi: 10.1097/00007890-199711150-00018

73. Sykes M, Pearson DA, Taylor PA, Szot GL, Goldman SJ, Blazar BR. Dose and timing of interleukin (IL)-12 and timing and type of total-body irradiation: Effects on graft-vs.-host disease inhibition and toxicity of exogenous IL-12 in murine bone marrow transplant recipients. Biol Blood Marrow Transplant. (1999) 5:277-84. doi: 10.1016/S1083-8791(99)70002-9

74. Yamamoto K, Shibata F, Miyasaka N, Miura O. (2002). The human perforin gene is a direct target of STAT4 activated by IL-12 in NK cells. Biochem. Biophys. Res. Commun. doi: 10.1016/S0006-291X(02)02378-1

75. Song Y, Hu B, Liu Y, Jin Z, Zhang Y, Lin D, et al. IL-12/IL-18-preactivated donor NK cells enhance GVL effects and mitigate GvHD after allogeneic hematopoietic stem cell transplantation. Eur J. Immunol. (2018) 48:670-82. doi: 10.1002/eji.201747177

76. Linterman MA, Vinuesa CG. Signals that influence $\mathrm{T}$ follicular helper cell differentiation and function. Semin Immunopathol. (2010) 32:183-96. doi: 10.1007/s00281-009-0194-Z

77. Schmitt N, Bustamante J, Bourdery L, Bentebibel SE, Boisson-Dupuis $\mathrm{S}$, Hamlin $\mathrm{F}$, et al. IL-12 receptor $\beta 1$ deficiency alters in vivo $\mathrm{T}$ follicular helper cell response in humans. Blood. (2013) 121:3375-85. doi: 10.1182/blood-2012-08-448902

78. Chen Z, Laurence A, Kanno Y, Pacher-Zavisin M, Zhu B-M, Tato $\mathrm{C}$, et al. Selective regulatory function of Socs3 in the formation of IL-17-secreting T cells. Proc Natl Acad Sci USA. (2006) 103:8137-42. doi: 10.1073/pnas.0600666103

79. Laurence A, O'Shea JJ. TH-17 differentiation: of mice and men. Nat Immunol. (2007) 8:903-5. doi: 10.1038/ni0907-903

80. Yang XO, Panopoulos AD, Nurieva R, Seon HC, Wang D, Watowich SS, et al. STAT3 regulates cytokine-mediated generation of inflammatory helper T cells. J Biol Chem. (2007) 282:9358-63. doi: 10.1074/jbc.C600321200

81. McGeachy MJ, Cua DJ. Th17 cell differentiation: the long and winding road. Immunity. (2008) 28:445-53. doi: 10.1016/j.immuni.2008.03.001

82. Codarri L, Gyülvészii G, Tosevski V, Hesske L, Fontana A, Magnenat L, et al. ROR $\gamma 3$ t drives production of the cytokine GM-CSF in helper T cells, which is essential for the effector phase of autoimmune neuroinflammation. Nat Immunol. (2011) 12:560-7. doi: 10.1038/ni.2027

83. El-Behi M, Ciric B, Dai H, Yan Y, Cullimore M, Safavi F, et al. The encephalitogenicity of TH17 cells is dependent on IL-1- and IL-23-induced production of the cytokine GM-CSF. Nat Immunol. (2011) 12:568-75. doi: 10.1038/ni.2031

84. Langrish CL, Chen Y, Blumenschein WM, Mattson J, Basham B, Sedgwick JD, et al. IL-23 drives a pathogenic T cell population that induces autoimmune inflammation. J Exp Med. (2005) 201:233-40. doi: 10.1084/jem.20041257

85. Meyer zu Horste G, Wu C, Wang C, Cong L, Pawlak M, Lee Y, et al. RBPJ controls development of pathogenic Th17 cells by regulating IL-23 receptor expression. Cell Rep. (2016) 16:392-404. doi: 10.1016/j.celrep.2016.05.088

86. Frauwirth KA, Riley JL, Harris MH, Parry RV, Rathmell JC, Plas DR, et al. The CD28 signaling pathway regulates glucose metabolism. Immunity. (2002)16:769-77. doi: 10.1016/S1074-7613(02)00323-0

87. Jacobs SR, Herman CE, MacIver NJ, Wofford JA, Wieman HL, Hammen JJ, et al. Glucose uptake is limiting in T cell activation and requires CD28mediated Akt-dependent and independent pathways. J Immunol. (2008) 180:4476-86. doi: 10.4049/jimmunol.180.7.4476

88. Hanahan D, Weinberg RA, Palazon A, Aragones J, Morales-Kastresana A, de Landazuri MO, et al. HIFlalpha-dependent glycolytic pathway orchestrates a metabolic checkpoint for the differentiation of TH17 and Treg cells. J Immunol. (2011) 208:1367-76. doi: 10.1084/jem.201 10278
89. Luo W, Hu H, Chang R, Zhong J, Knabel M, O’Meally R, et al. Pyruvate kinase M2 is a PHD3-stimulated coactivator for hypoxia-inducible factor 1. Cell. (2011) 145:732-44. doi: 10.1016/j.cell.2011.03.054

90. Peter K, Rehli M, Singer K, Renner-Sattler K, Kreutz M. Lactic acid delays the inflammatory response of human monocytes. Biochem Biophys Res Commun. (2015) 457:412-8. doi: 10.1016/j.bbrc.2015.01.005

91. Semenza GL. Regulation of metabolism by hypoxia-inducible factor 1. Cold Spring Harb. Symp Quant Biol. (2011) 76:347-53. doi: 10.1101/sqb.2011.76.010678

92. Gao X, Wang H, Yang JJ, Liu X, Liu ZR. Pyruvate kinase M2 regulates gene transcription by acting as a protein kinase. Mol Cell. (2012) 45:598-609. doi: 10.1016/j.molcel.2012.01.001

93. Lochmatter C, Fischer R, Charles PD, Yu Z, Powrie F, Kessler BM. Integrative phosphoproteomics links IL-23R signaling with metabolic adaptation in lymphocytes. Sci Rep. (2016) 6:24491. doi: 10.1038/srep24491

94. Kleinewietfeld M, Manzel A, Titze J, Kvakan H, Yosef N, Linker RA, et al. Sodium chloride drives autoimmune disease by the induction of pathogenic TH 17 cells. Nature. (2013) 496:518-22. doi: 10.1038/nature11868

95. Wu C, Yosef N, Thalhamer T, Zhu C, Xiao S, Kishi Y, et al. Induction of pathogenic TH 17 cells by inducible salt-sensing kinase SGK1. Nature. (2013) 496:513-7. doi: 10.1038/nature11984

96. Jain R, Chen Y, Kanno Y, Joyce-Shaikh B, Vahedi G, Hirahara K, et al. Interleukin-23-induced transcription factor blimp-1 promotes pathogenicity of $\mathrm{T}$ helper 17 cells. Immunity. (2016) 44:131-142. doi: 10.1016/j.immuni.2015.11.009

97. Ahern PP, Schiering C, Buonocore S, McGeachy MJ, Cua DJ, Maloy KJ, et al. Interleukin-23 drives intestinal inflammation through direct activity on $\mathrm{T}$ cells. Immunity. (2010) 33:279-88. doi: 10.1016/j.immuni.2010.08.010

98. Buonocore S, Ahern PP, Uhlig HH, Ivanov II, Littman DR, Maloy KJ, et al. Innate lymphoid cells drive interleukin-23-dependent innate intestinal pathology. Nature. (2010) 464:1371-5. doi: 10.1038/nature08949

99. Hue S, Ahern P, Buonocore S, Kullberg MC, Cua DJ, McKenzie BS, et al. Interleukin-23 drives innate and T cell-mediated intestinal inflammation. $J$ Exp Med. (2006) 203:2473-83. doi: 10.1084/jem.20061099

100. Tonel G, Conrad C, Laggner U, Di Meglio P, Grys K, McClanahan TK, et al. Cutting edge: a critical functional role for IL-23 in psoriasis. J Immunol. (2010) 185:5688-91. doi: 10.4049/jimmunol.1001538

101. Liu Y, Cai Y, Dai L, Chen G, Ma X, Wang Y, et al. The expression of Th17associated cytokines in human acute graft-versus-host disease. Biol Blood Marrow Transplant. (2013) 19:1421-9. doi: 10.1016/j.bbmt.2013.06.013

102. Elmaagacli AH, Koldehoff M, Landt O, Beelen DW. Relation of an interleukin-23 receptor gene polymorphism to graft-versus-host disease after hematopoietic-cell transplantation. Bone Marrow Transplant. (2008) 41:8216. doi: 10.1038/sj.bmt.1705980

103. Buchele V, Abendroth B, Büttner-Herold M, Vogler T, Rothamer J, Ghimire $\mathrm{S}$, et al. Targeting inflammatory $\mathrm{T}$ helper cells via retinoic acid-related orphan receptor gamma t is ineffective to prevent allo-response-driven colitis. Front Immunol. (2018) 9:1138. doi: 10.3389/fimmu.2018.01138

104. Bloch Y, Bouchareychas L, Merceron R, Składanowska K, Van den Bossche L, Detry S, et al. Structural activation of pro-inflammatory human cytokine IL-23 by cognate IL-23 receptor enables recruitment of the shared receptor IL-12Rß1. Immunity. (2018) 48:45-58.e6. doi: 10.1016/j.immuni.2017.12.008

105. Desmet J, Verstraete K, Bloch Y, Lorent E, Wen Y, Devreese B, et al. Structural basis of IL-23 antagonism by an Alphabody protein scaffold. Nat Commun. (2014) 5:5237. doi: 10.1038/ncomms6237

106. Sayago C, Gonzalez Valcarcel IC, Qian Y, Lee J, Alsina-Fernandez J, Fite NC, et al. Deciphering binding interactions of IL-23R with HDX-MS: mapping protein and macrocyclic dodecapeptide ligands. ACS Med Chem Lett. (2018) 9:912-6. doi: 10.1021/acsmedchemlett.8b00255

107. Schröder J, Moll JM, Baran P, Grötzinger J, Scheller J, Floss DM. Non-canonical interleukin 23 receptor complex assembly: P40 protein recruits interleukin 12 receptor $\beta 1$ via site II and induces P19/interleukin 23 receptor interaction via site III. J Biol Chem. (2015) 290:359-70. doi: 10.1074/jbc.M114.617597

108. Yoon C, Johnston SC, Tang J, Stahl M, Tobin JF, Somers WS Charged residues dominate a unique interlocking topography in the heterodimeric cytokine interleukin-12. EMBO J. (2000) 19:3530-41. doi: 10.1093/emboj/19.14.3530 
109. Quiniou C, Dominguez-Punaro M, Cloutier F, Erfani A, Ennaciri J, Sivanesan $\mathrm{D}$, et al. Specific targeting of the IL-23 receptor, using a novel small peptide noncompetitive antagonist, decreases the inflammatory response. AJP Regul Integr Comp Physiol. (2014) 307:R1216-30. doi: 10.1152/ajpregu.00540.2013

110. Heinzel FP, Hujer AM, Ahmed FN, Rerko RM. In vivo production and function of IL-12 p40 homodimers. J Immunol. (1997) 158:4381-8.

111. Russell TD, Yan Q, Fan G, Khalifah AP, Bishop DK, Brody SL, et al. IL-12 p40 homodimer-dependent macrophage chemotaxis and respiratory viral inflammation are mediated through IL-12 receptor beta 1. J Immunol. (2003) 171:6866-74.

112. Piccotti JR, Chan SY, Li K, Eichwald EJ, Bishop DK. Differential effects of IL12 receptor blockade with IL-12 p40 homodimer on the induction of CD4+ and CD8+ IFN-gamma-producing cells. J Immunol. (1997) 158:643-8.

113. Gillessen S, Carvajal D, Ling P, Podlaski FJ, Stremlo DL, Familletti PC, et al. Mouse interleukin-12 (IL-12) p40 homodimer: a potent IL-12 antagonist. Eur J Immunol. (1995) 25:200-6. doi: 10.1002/eji.1830250133

114. Annunziato F, Cosmi L, Santarlasci V, Maggi L, Liotta F, Mazzinghi B, et al. Phenotypic and functional features of human Th17 cells. J Exp Med. (2007) 204:1849-61. doi: 10.1084/jem.20070663

115. Lexberg MH, Taubner A, Förster A, Albrecht I, Richter A, Kamradt T, et al. Th memory for interleukin-17 expression is stable in vivo. Eur J Immunol. (2008) 38:2654-64. doi: 10.1002/eji.200838541

116. Okamoto S, Fujiwara H, Nishimori H, Matsuoka K, Fujii N, Kondo E, et al. Anti-IL-12/23 p40 antibody attenuates experimental chronic graft-versushost disease via suppression of IFN- $\gamma /$ IL-17-producing cells. J Immunol. (2015) 194:1357-63. doi: 10.4049/jimmunol.1400973

117. Wu Y, Bastian D, Schutt S, Nguyen H, Fu J, Heinrichs J, et al. Essential role of interleukin-12/23p40 in the development of graft-versus-host disease in mice. Biol. Blood Marrow Transplant. (2015) 21:1195-204. doi: 10.1016/j.bbmt.2015.03.016

118. Pidala J, Beato F, Kim J, Betts B, Jim H, Sagatys E, et al. In vivo IL-12/IL-23p40 neutralization blocks Th1/Th17 response after allogeneic hematopoietic cell transplantation. Haematologica. (2018) 103:531-9. doi: 10.3324/haematol.2017.171199

119. Cua DJ, Sherlock J, Chen Y, Murphy CA, Joyce B, Seymour B, et al. Interleukin-23 rather than interleukin-12 is the critical cytokine for autoimmune inflammation of the brain. Nature. (2003) 421:744-8. doi: 10.1038/nature01355

120. Chua A, Presky DH, Cubler U. Cloning and characterization of a mouse IL-12 receptor-beta component. J Immunol. (1995) 55:4286-94.

121. Altare F, Durandy A, Lammas D, Emile JF, Lamhamedi S, Le Deist F, et al. Impairment of mycobacterial immunity in human interleukin-12 receptor deficiency. Science. (1998) 280:1432-5. doi: 10.1126/science.280.5368.1432

122. De Jong R, Altare F, Haagen IA, Elferink DG, De Boer T, Van Breda Vriesman PJC, et al. Severe mycobacterial and Salmonella infections in interleukin-12 receptor-deficient patients. Science. (1998) 280:1435-8. doi: $10.1126 /$ science.280.5368.1435

123. Losana G, Rigamonti L, Borghi I, Assenzio B, Ariotti S, Jouanguy E, et al. Requirement for both IL-12 and IFN- $\gamma$ signaling pathways in optimal IFN$\gamma$ production by human T cells. Eur J Immunol. (2002) 32:693-700. doi: 10 . 1002/1521-4141(200203)32:3<693::AID-IMMU693>3.0.CO;2-Q

124. Fieschi C, Casanova JL. The role of interleukin-12 in human infectious diseases: Only a faint signature. Eur J Immunol. (2003) 33:1461-4. doi: 10.1002/eji.200324038

125. Takahashi N, Akahoshi M, Matsuda A, Ebe K, Inomata N, Obara K, et al. Association of the IL12RB1 promoter polymorphisms with increased risk of atopic dermatitis and other allergic phenotypes. Hum Mol Genet. (2005) 14:3149-59. doi: 10.1093/hmg/ddi347

126. Koch MA, Thomas KR, Perdue NR, Smigiel KS, Srivastava S, Campbell DJ. T-bet+Treg Cells Undergo Abortive Th1 Cell Differentiation due to Impaired Expression of IL-12 Receptor $\beta 2$. Immunity. (2012) 37:501-10. doi: 10.1016/j.immuni.2012.05.031

127. Ling G, Ling E, Broides A, Poran Feldman H, Levy J, Garty BZ, et al. IL-12 receptor $1 \beta$ deficiency with features of autoimmunity and photosensitivity. Autoimmunity. (2016) 49:143-6. doi: 10.3109/08916934.2015.1134513

128. Schmitt N, Liu Y, Bentebibel SE, Munagala I, Bourdery L, Venuprasad K, et al. The cytokine TGF- $\beta 2$ co-opts signaling via STAT3-STAT4 to promote the differentiation of human TFHcells. Nat Immunol. (2014) 15:856-65. doi: 10.1038/ni.2947

129. Pflanz S, Timans JC, Cheung J, Rosales R, Kanzler H, Gilbert J, et al. IL-27, a heterodimeric cytokine composed of EBI3 and p28 protein, induces proliferation of naive CD4+T cells. Immunity. (2002) 16:779-90. doi: 10.1016/S1074-7613(02)00324-2

130. Shimozato O, Sato A, Kawamura K, Chiyo M, Ma G, Li Q, et al. The secreted form of p28 subunit of interleukin (IL)-27 inhibits biological functions of IL27 and suppresses anti-allogeneic immune responses. Immunology. (2009) 128(1 Suppl.):e816-25. doi: 10.1111/j.1365-2567.2009.03088.x

131. Stumhofer JS, Tait ED, Iii WJQ, Hosken N, Spudy B, Goenka R, et al. A role for IL-27p28 as an antagonist of gp130-mediated signaling. Nat Immunol. (2010) 11:1119-26. doi: 10.1038/ni.1957

132. Dietrich C, Candon S, Ruemmele FM, Devergne O. A soluble form of IL-27R is a natural IL-27 antagonist. J Immunol. (2014) 192:5382-9. doi: 10.4049/jimmunol.1303435

133. Shen P, Roch T, Lampropoulou V, O'Connor RA, Stervbo U, Hilgenberg E, et al. IL-35-producing B cells are critical regulators of immunity during autoimmune and infectious diseases. Nature. (2014) 507:366-70. doi: 10.1038/nature12979

134. Zhang X.-H, Zhou Y, Zhou S, Feng F, Wang Q, Han W, et al. IL-35 and rapamycin reduce acute graft-versus-host disease associated with decreased platelet aggregation in a mouse model. Blood. (2014) 124:3814.

135. Turnis ME, Sawant DV, Szymczak-Workman AL, Andrews LP, Delgoffe GM, Yano H, et al. Interleukin-35 limits anti-tumor immunity. Immunity. (2016) 44:316-29. doi: 10.1016/j.immuni.2016.01.013

136. Zongyi Y, Funian Z, Hao L, Xin W, Ying C, Jialin Z, et al. Interleukin35 mitigates the function of murine transplanted islet cells via regulation of Treg/Th17 ratio. PLoS ONE. (2017) 12:e0189617. doi: 10.1371/journal.pone.0189617

137. Wang X, Wei Y, Xiao H, Liu X, Zhang Y, Han G, et al. A novel IL-23p19/Ebi3 (IL-39) cytokine mediates inflammation in Lupus-like mice. Eur J Immunol. (2016) 46:1343-50. doi: 10.1002/eji.201546095

138. Ramnath D, Tunny K, Hohenhaus DM, Pitts CM, Bergot AS, Hogarth PM, et al. TLR3 drives IRF6-dependent IL-23p19 expression and p19/EBI3 heterodimer formation in keratinocytes. Immunol Cell Biol. (2015) 93:771-9. doi: 10.1038/icb.2015.77

139. Silver JS, Hunter CA. gp130 at the nexus of inflammation, autoimmunity, and cancer. J Leukoc Biol. (2010) 88:1145-56. doi: 10.1189/jlb.0410217

140. Wolf J, Rose-John S, Garbers C. Interleukin-6 and its receptors: a highly regulated and dynamic system. Cytokine. (2014) 70:11-20. doi: 10.1016/j.cyto.2014.05.024

141. Wang X, Lupardus P, LaPorte SL, Garcia KC. Structural biology of shared cytokine receptors. Annu Rev Immunol. (2009) 27:29-60. doi: 10.1146/annurev.immunol.24.021605.090616

142. Blauvelt A, Reich K, Mehlis S, Vanaclocha F, Sofen H, Abramovits W, et al. Secukinumab demonstrates greater sustained improvements in daily activities and personal relationships than ustekinumab in patients with moderate-to-severe plaque psoriasis: 52 -week results from the CLEAR study. J Eur Acad Dermatol Venereol. (2017) 31:1693-9. doi: 10.1111/jdv.14391

143. Reich K, Papp KA, Blauvelt A, Tyring SK, Sinclair R, Thaçi D, et al. Tildrakizumab versus placebo or etanercept for chronic plaque psoriasis (reSURFACE 1 and reSURFACE 2): results from two randomised controlled, phase 3 trials. Lancet. (2017) 390:276-88. doi: 10.1016/S0140-6736(17)31279-5

144. Betts BC, Bastian D, Iamsawat S, Nguyen H, Heinrichs JL, Wu Y, et al. Targeting JAK2 reduces GVHD and xenograft rejection through regulation of T cell differentiation. Proc Natl Acad Sci USA. (2018) 115:1582-7. doi: 10.1073/pnas.1712452115

145. Betts BC, Abdel-Wahab O, Curran SA, St Angelo ET, Koppikar P, Heller $\mathrm{G}$, et al. Janus kinase-2 inhibition induces durable tolerance to alloantigen by human dendritic cell-stimulated $\mathrm{T}$ cells yet preserves immunity to recall antigen. Blood. (2011a) 118:5330-9. doi: 10.1182/blood-2011-06-3 63408

146. Spoerl S, Mathew NR, Bscheider M, Schmitt-Graeff A, Chen S, Mueller T, et al. Activity of therapeutic JAK $1 / 2$ blockade in graft-versus-host disease. Blood. (2014) 123:3832-42. doi: 10.1182/blood-2013-12-543736 
147. Steward-Tharp SM, Laurence A, Kanno Y, Kotlyar A, Villarino AV, Sciume G, et al. A mouse model of HIES reveals pro- And anti-inflammatory functions of STAT3. Blood. (2014) 123:2978-87. doi: 10.1182/blood-2013-09-523167

148. Teng MWL, Bowman EP, McElwee JJ, Smyth MJ, Casanova JL, Cooper AM, et al. IL-12 and IL-23 cytokines: From discovery to targeted therapies for immune-mediated inflammatory diseases. Nat Med. (2015) 21:719-29. doi: 10.1038/nm.3895

149. Kennedy GA, Varelias A, Vuckovic S, Le Texier L, Gartlan KH, Zhang P, et al. Addition of interleukin-6 inhibition with tocilizumab to standard graft-versus-host disease prophylaxis after allogeneic stemcell transplantation: a phase 1/2 trial. Lancet Oncol. (2014) 15:1451-9. doi: 10.1016/S1470-2045(14)71017-4

150. Betts BC, St Angelo ET, Kennedy M, Young JW. Anti-IL6-receptor-alpha (tocilizumab) does not inhibit human monocyte-derived dendritic cell maturation or alloreactive T-cell responses. Blood. (2011b) 118:5340-3. doi: 10.1182/blood-2011-06-363390

151. Pidala J, Perez L, Beato F, Anasetti C. Ustekinumab demonstrates activity in glucocorticoid-refractory acute GVHD. Bone Marrow Transplant. (2011) 47:747. doi: 10.1038/bmt.2011.172

152. Harrison C, Kiladjian, J.-J, Al-Ali HK, Gisslinger H, Waltzman R, Stalbovskaya V, et al. JAK inhibition with Ruxolitinib versus best available therapy for myelofibrosis. $N$ Engl J Med. (2012) 366:787-98. doi: 10.1056/NEJMoa1110556

153. Carniti C, Gimondi S, Vendramin A, Recordati C, Confalonieri D, Bermema A, et al. Pharmacologic inhibition of JAK1/JAK2 signaling reduces Experimental murine acute GVHD while preserving GVT effects. Clin Cancer Res. (2015) 21:3740-9. doi: 10.1158/1078-0432.CCR-1 4-2758

154. Choi J, Ziga ED, Ritchey J, Collins L, Prior JL, Cooper ML, et al. IFN $\gamma \mathrm{R}$ signaling mediates alloreactive T-cell trafficking and GVHD. Blood. (2012) 120:4093-103. doi: 10.1182/blood-2012-01-4 03196
155. Choi J, Cooper ML, Alahmari B, Ritchey J, Collins L, Holt M, et al. Pharmacologic blockade of JAK1/JAK2 reduces GvHD and preserves the graft-versus-leukemia effect. PLoS ONE. (2014) 9:e109799. doi: 10.1371/journal.pone.0109799

156. Zeiser R, Burchert A, Lengerke C, Verbeek M, Maas-Bauer K, Metzelder SK, et al. Ruxolitinib in corticosteroid-refractory graft-versus-host disease after allogeneic stem cell transplantation: a multicenter survey. Leukemia. (2015) 29:2062-8. doi: 10.1038/leu.2015.212

157. Curran SA, Shyer JA, St. Angelo ET, Talbot LR, Sharma S, Chung DJ, et al. Human Dendritic cells mitigate NK-cell dysfunction mediated by nonselective JAK1/2 blockade. Cancer Immunol Res. (2017) 5:52-60. doi: 10.4102/sajhrm.v12i1.650

158. Parampalli Yajnanarayana S, Stübig T, Cornez I, Alchalby H, Schönberg $\mathrm{K}$, Rudolph J, et al. JAK1/2 inhibition impairs $\mathrm{T}$ cell function in vitro and in patients with myeloproliferative neoplasms. Br J Haematol. (2015) 169:824-33. doi: 10.1111/bjh.13373

159. Schönberg K, Rudolph J, Vonnahme M, Yajnanarayana SP, Cornez I, Hejazi $M$, et al. JAK inhibition impairs NK cell function in myeloproliferative neoplasms. Cancer Res. (2015) 75:2187-99. doi: 10.1158/0008-5472.CAN-14-3198

Conflict of Interest Statement: The authors declare that the research was conducted in the absence of any commercial or financial relationships that could be construed as a potential conflict of interest.

Copyright (c) 2019 Bastian, Wu, Betts and Yu. This is an open-access article distributed under the terms of the Creative Commons Attribution License (CC BY). The use, distribution or reproduction in other forums is permitted, provided the original author(s) and the copyright owner(s) are credited and that the original publication in this journal is cited, in accordance with accepted academic practice. No use, distribution or reproduction is permitted which does not comply with these terms. 